\title{
Forstått og respektert
}

Intervju med LEVEs generalsekretær Lillian Erichsen

Ved Kari Wille Rekdal

Lillian Erichsen er den nye generalsekretæren i Lansdforeningen for etterlatte ved selvmord (LEVE), den første heltidsansatte leder LEVE har hatt. Hun begynte i jobben 1. februar i år, omtrent samtidig som sekretariatet i LEVE flyttet inn i nye, åpne og lyse lokaler i Oslo sentrum. Lillian Erichsen er 53 år, hun er gift og bor i Åsgårdstrand, har tre barn og to bonusbarn. Erichsen er utdannet statsviter, og har bred erfaring i ledelse fra frivillige organisasjoner i tillegg til erfaring fra lokalpolitikk, undervisning og barnevern.

Kjente du til LEVE før du søkte jobben som generalsekretær? Hvilket inntrykk hadde du $i$ så fall av organisasjonen?

-Jeg visste ikke så mye om LEVE, men kjente til organisasjonen gjennom media. Jeg leste tilfeldigvis om Vestfold fylkeslag i Tønsbergs Blad, som er lokalavisen min. Jeg fikk et veldig godt inntrykk av arbeidet deres. Så da annonsen hvor LEVE s $\varnothing$ kte etter generalsekretær kom, hadde jeg en positiv oppfatning av organisasjonen. Dessuten synes jeg at stillingen som generalsekretær er spennende, og ikke minst er det flott å bli ansatt i et jubileumsår. Ved å ansette en generalsekretær signaliserer LEVE at de satser profesjonelt, er på dagsordenen.

Har du erfaring og personlige egenskaper som kan være spesielt nyttige eller viktige for LEVE?

- Jeg har jobbet mye som leder i frivillig arbeid, innenfor rus, kvinner og helse TV-aksjonen, blant annet. Jeg engasjerer meg for å bedre levekårene for folk. Jeg har frontet stemmer som ikke når frem til vanlig, det synes jeg er viktig og meningsfullt.

\section{Forutsigbarhet og finansiering}

Du er LEVEs første heltidsansatte generalsekretær og etterfølger Finn Borgersen som fortsatt er styreleder. Han har lagt stor vekt på organisasjonsbygging, slik at LEVE nå er til stede på lokalnivå $i$ alle fylker. Hva vil du forst og fremst legge vekt på?

- Det viktigste nå er å sikre finansiering. En av grunnene til at sentralstyret gikk inn for å ansette en leder på heltid, var nettopp å kunne jobbe enda mer strategisk for å sikre forutsigbarhet og finansiering. Så noe av det første jeg gjorde i denne jobben, var å komme i dialog med helseminister Anne-Grete Strøm-Erichsen. Vi har vært i møte med henne og presentert LEVE og arbeidet vi driver, både sentralt og lokalt. Vi møtte stor forståelse hos ministeren. LEVE er jo unike i det at man ikke kan drive med medlemsrekruttering for å skaffe inntekter via medlemskontingenten og statstilskuddet. Det ville jo være helt uetisk å s $\varnothing$ ke aktivt etter medlemmer i en organisasjon som vår. Samtidig er det umulig å jobbe strategisk når man hele tiden må bruke tid og krefter på å skaffe penger. Vi ønsker oss en fast post til driftsmidler for å slippe å bruke så mye tid og ressurser på å s $\varnothing$ ke prosjektbasert finansiering. Selvmord som samfunnsproblem har helsepolitiske konsekvenser, og det er helseministeren fullstendig klar over.

-På samme måte som kreft gjør, rammer selvmord bredt, og jeg skulle $\varnothing$ nske at vi i st $\varnothing$ rre grad så dødsannonser hvor etterlatte $\varnothing$ nsker gave til LEVE fremfor blomster, og at flere $\varnothing$ nsket å gi penger i gave til LEVE, slik som mange gjør til Kreftforeningen.

- Ellers er jo lokal organisering helt grunnleggende. Sekretariatet skal etter min mening være en formidlingssentral for alt det som skjer på lokalt nivå - fagdager, kaféer, sorggrupper og så videre. Men for at det skal fungere slik, fordrer det et tilbud, og derfor har den organisasjonsbyggingen som har pågått til nå, vært helt grunnleggende nødvendig. Nå som de lokale enhetene er på plass, er det sekretariatets oppgave å stå til tjeneste for organisasjonen. Fremover nå skal jeg bes $\varnothing$ ke fylkeslagene og se på deres aktiviteter, få kontakt og bli kjent. Jeg har allerede vært hos noen, og i kveld skal jeg på Kafé LEVE hos Oslo fylkeslag.

\section{Myndighetene og fagmiljøene}

Kan du nevne noen viktige omrader og temaer som du vil at LEVE skal satse på eller være tydelige på fremover?

- Jeg er, i likhet med de fleste etterlatte, opptatt av åpenhet, det er et viktig tema. Appenhet letter m $\varnothing$ tet med omgivelsene, det er lettere for andre å ta kontakt når det ikke er noen hemmelighet.

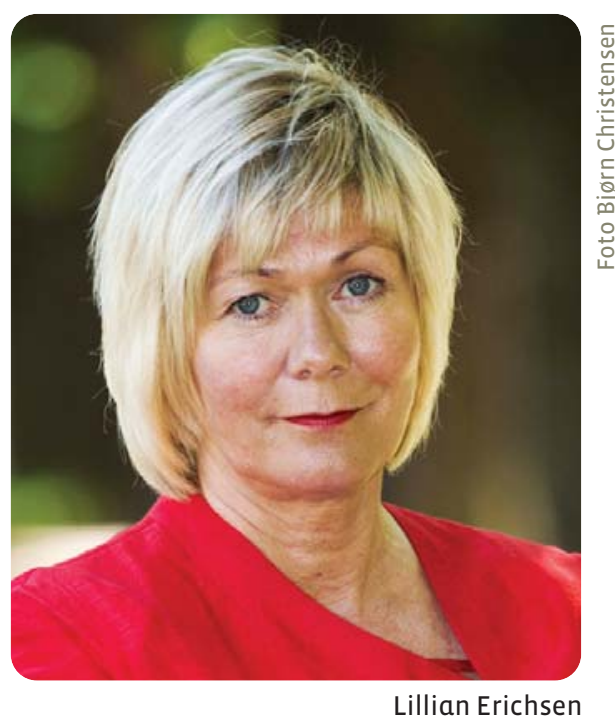

- Et annet tema er at det er LEVEs oppgave å ta veldig alvorlig de tilbakemeldingene vi får fra etterlatte, blant annet har LEVE en viktig oppgave i å se til at for eksempel Nasjonale retningslinjer for forebygging av selvmord i psykisk helsevern blir fulgt. Der har vi vært i møte med Helsetilsynet, det var et veldig godt møte, og for LEVE er det viktig å være i dialog med myndighetene og fagmiljøene. Det er mål nummer én for LEVE å få frem nødvendigheten av at etterlatte blir forstått og respektert for den situasjonen de er i. For å få formidlet dette må man være i dialog med alle parter. Deretter må vi spørre: Hvordan kan vi kvalitetssikre tjenestene til etterlatte? Hva slags hjelp trenger de, og hvordan skal hjelpen gis? LEVEs medlemmer har en erfaringsbasert kompetanse å bidra med, ikke minst overfor forskningsmiljøet. Forskning og erfaring hånd i hånd; det er en veldig viktig pragmatisk tilnærming fra LEVE. Viktigheten av det nasjonale nettverket for etterlatte ved selvmord blir tydelig i denne sammenhengen. LEVE skal selvfølgelig også ha fokus på å jobbe forebyggende, og da er markeringen av Verdensdagen for selvmordsforebygging 10. september særlig viktig. 


\section{LEVEs 10-ÅRSJUBILEUM - $\AA$ LEVE LIVET-}

- Enda et viktig område er arbeidet med å kartlegge alle de kommunale kriseteamene. Vi skal ha møte med Kommunenes sentralforbund om hvordan LEVE kan bli en del av dette. Det skal ikke være et eneste kommunalt kriseteam i Norge som ikke er klar over at LEVE finnes.

- Jeg tror jeg kan si at det er fire miljøer som det er viktig at LEVE er i kontinuerlig kontakt og dialog med, og det er Helsetilsynet, helsemyndighetene, Kommunenes sentralforbund og fagmiljøene. Vi i LEVE har gjennom vår erfaring fătt en viktig kompetanse, og det er viktig å samle den og jobbe tverrfaglig, for da kommer brukeren i fokus.

Vi har jo snakket om at selumord dessverre er noe som rammer bredt. Har du selv noen gang blitt rammet?

- Jeg har opplevd selvmord i egen familie. Denne erfaringen kommer godt med i møtet med den flotte organisasjonen LEVE. Imidlertid var ikke det drivkraften for å søke denne jobben.

\section{LEVE jubilerer}

LEVE feirer sine ti forste år. Hvis du fikk bruke førstesiden til en riksdekkende avis for a markere det, hva ville du fylt den med?

- Da ville jeg fylt den med mer av det jeg har snakket om her. Jeg ville vise hva vi har fått til så langt og feire oss selv. Så ville jeg få frem det som forskere har påvist, og summere opp: Hva vet vi? Denne kunnskapen kan brukes, til å gi håp, til å feire livet. LEVE og det arbeidet vi har gjort, kan vise at det er mulig å komme seg gjennom et slikt tap og gå videre.

Har du et motto for LEVE?

- Det må være Forstått og respektert. Det synes jeg er grunnleggende viktig, at etterlatte blir forstått og respektert for den situasjonen de er i. I boken Etter selumordet - veien videre bruker forfatterne Kari Dyregrov, Einar Plyhn og Gudrun Dieserud ofte uttrykket "å komme gjennom det, selv om man ikke kommer over det". 1) Men jeg holder på førstevalget mitt. Det er slik vi $\varnothing$ nsker at andre skal forholde seg til LEVE.

1) Dyregrov K, Plyhn E, Dieserud G: Etter selvmordet: veien videre. Oslo: Abstrakt, 2010 - 240 s. ISBN 978-82-7935-274-7

Se anmeldelse s. 28.

I desember 1999 ble LEVE stiftet. 10 års fruktbart arbeid er lagt ned av etterlatte, frivillige og fagpersoner, slik at mennesker som mister sine kjære i selvmord skal få den hjelpen og omsorgen de trenger. Samtidig har etterlatte bidratt med egne historier og opplevelser, i håp om at selvmord reduseres som et samfunnstabu.

Håpet er den viktigste drivkraft $\mathbf{i}$ LEVE sitt arbeid.

Håp om at færre liv skal gå tapt. Håp for etterlattes liv videre, når selvmordet likevel har rammet.

Med jubileumskonferansen i Oslo 3.-4. juni $\varnothing$ nsket LEVE å hedre arbeidsinnsatsen som er lagt ned, samt markere stiftelsen av en organisasjon som har blitt så viktig for så mange mennesker.

Konferansen samlet rundt 200 mennesker, både etterlatte ved selvmord og fagfolk. Foredragsholderne tok for en stor del opp temaer rundt det å være etterlatt og deres behov for hjelp og st $\varnothing$ tte, om sorgprosessen, om hvordan man kan komme seg videre for å møte livets utfordringer, og hva LEVE kan bidra med for å forebygge selvmord. Foredragene ble holdt på en varm og ivaretakende måte, noe som skapte en god stemning. De som var til stede, fikk med seg stoff til ettertanke og ny lærdom.

LEVE-prisen ble delt ut for første gang under konferansen.
Tre personer, som har gjort en betydelig innsats for organisasjonen helt fra starten av, ble hedret:

Finn Borgersen har vært LEVEs styreleder siden starten. Han har bygget organisasjonen stein for stein og vist enormt engasjement og vilje til å drive frem organisasjonen med et klart hode og et varmt hjerte.

Lars Mehlum var en av initiativtagerne til LEVE. Som leder av Nasjonalt senter for selvmordsforskning og -forebygging har Lars Mehlum hele tiden vært en svært god st $\varnothing$ ttespiller for LEVE. Hjelpen og st $\varnothing$ tten fra senteret var også av helt avgjørende betydning for LEVE i etableringsfasen.

Kari Dyregrov var en av initiativtagerne av LEVE, og spesielt hennes kontaktnett av frivillige fra sitt forskerarbeid gjorde etableringen av landsstyret svært mye lettere samt hennes erfaringer fra etablering av liknende organisasjoner. Kari Dyregrov har i alle år både som styremedlem og fagperson spilt en svært viktig rolle for driften av LEVE.
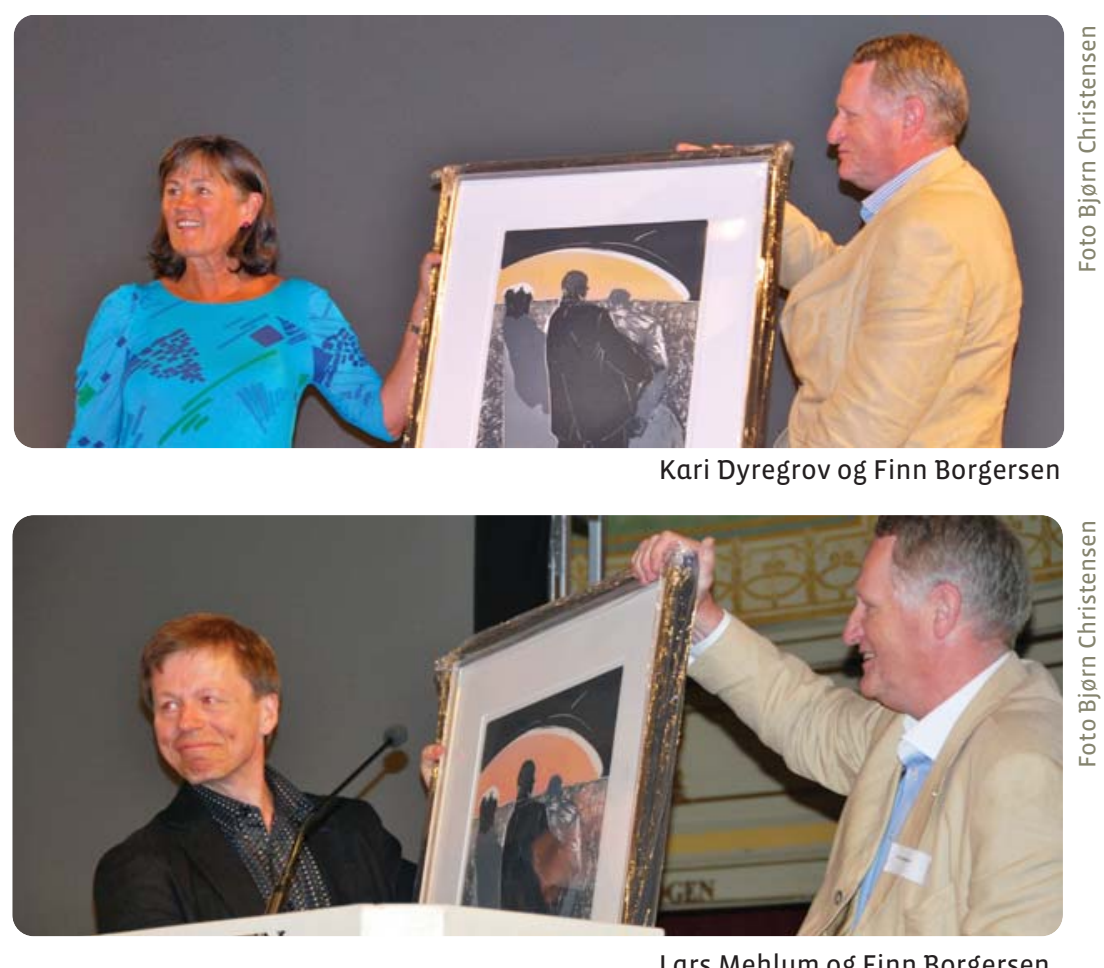

Lars Mehlum og Finn Borgersen 